\title{
収穫後チャービルの低温貯蔵のための赤色発光ダイオード による弱光照射および養液ゲル利用
}

\author{
富士原和宏・高 久晃一・飯 本 光 雄 \\ 千葉大学園芸学部
}

Low Light Irradiation Using Red Light Emitting Diodes and Nutrient Gel Application for Low Temperature Storage of Postharvest Chervil (Anthriscus cerefoliun L.)

Kazuhiro Fujiwara, Koichi TaKaKu and Mitsuo IImoto

Faculty of Horticulture, Chiba University, Matsudo, Chiba 271, Japan

\begin{abstract}
Postharvest chervil, a kind of culinary herb, stored at $8.0^{\circ} \mathrm{C}$ under low light irradiation (LLI : $1 \mu \mathrm{mol} \mathrm{m}^{-2} \mathrm{~s}^{-1}$ PPFD) with nutrient gel application (NGA) to the cut ends of the stems showed similar changes in chromaticity $\left(L^{*}, a^{*}, b^{*}\right.$ and $\left.\Delta E^{*} a b\right)$ values for 21 days of the storage period to that stored at $6.8^{\circ} \mathrm{C}$ under darkness with NGA. Low light was provided with an array of red light emitting diodes (red LEDs). Postharvest chervil stored without NGA showed markedly greater values in $L^{*}, a^{*}$ and $\Delta E^{*} a b$ after day 9 of the storage than that stored with NGA at $8.0^{\circ} \mathrm{C}$ under LLI. LLI using red LEDs with NGA proved highly effective for preserving the visual quality of postharvest chervil during low temperature storage.
\end{abstract}

(Received December 17, 1996)

1996 年 12 月 17 日受付

\section{緒言}

低温貯蔵中のセル成型苗に弱光を照射する（以下, 弱光照射）と貯蔵期間の延長に効果のあることが, Heins et al. (1994) によって十数品目の花卉について 実証されまとめられた。 その後, その興味深い実証結 果に刺激されて，ブロッコリ組織培養苗 (Kubota and Kozai, 1994)，ナスセル成型苗（Kozai et al., 1996）, および収穫後のカイワレダイコン (Kobayashi et al., 1996)の低温貯蔵における弱光照射の効果が調べられ, 同様に効果のあることが確認された。これらの報告は, 培養土, 培地などから, 水と養分, あるいは水のみを 吸収できる条件下にある植物体に対しては，低温貯蔵 中の弱光照射が有効であることを示すものである.し かし，多くの緑色青果物や挿し穂のように，水や養分 の供給源がない条件下にある緑色植物体に対する弱光 照射の効果についての報告や，そのような植物体に水 と養分を供給しながら弱光照射の効果を調べた報告は ない.さらにまた，上記の報告ではすべて光源として

Vol. 35, No. 2 (1997)
白色蛍光灯を用いているが，次に示す理由から，白色 蛍光灯よりも低輝度の赤色発光ダイオードの方が実用 的な弱光照射低温貯蔵に適していると考える.その理 由は, 1) 赤 (ピーク波長 : $660 \mathrm{~nm}$ ) は光合成に特に有 効な波長帯，2）発光ダイオードは蛍光灯に比較して 数倍以上長寿命，3）低輝度でかつ点光源に近い形状 であることが弱光の均一照射に好適，4）高輝度, 超高 輝度の発光ダイオードに比較して著しく安価,である.

そこで, 筆者らは低輝度の赤色発光ダイオードによ る弱光照射の有無, および植物育成用の養液をゲル化 したもの（以下，養液ゲル）の利用の有無が，収穕後 チャービルの低温貯蔵中の外観品質, 特に葉色の経日 変化に及ぼす影響を調べることを目的とした一連の試 験を開始した。ここでは, その予備的試験により得ら れた葉色の経日変化, 貯蔵後の生体重および乾物重に ついての結果を報告する.

\section{材料および方法}

供試植物には，セコムハイプラント(株)において， 1996 年 4 月 15 日に播種, ガラス温室 (設定気温：18- 
$\left.24^{\circ} \mathrm{C}\right)$ 内で DFT (Deep Flow Technique) 水耕栽培さ れ, 同年 6 月 1 日に収穫されたチャービル (Anthriscus cerefolium L.) を用いた. チャービルは, 主に生鮮で料 理に用いられるハーブ (香草) の一種であり, 鮮度低 下が著しく速く (Cantwell and Reid, 1990), また重量 当たりの市場価格が高いため貯蔵技術の確立が望まれ ている品目である。チャービルは, 収穫後直ちに収穫 地（宮城）より試験地（千葉）まで配送業者により低 温輸送（所要時間：24 時間以内）された後, 透明プラ スチック袋 (以後, 単に袋)に 1 袋当たり 20 本ずつ入 れられ, 恒温チャンバ内で 21 日間貯蔵された. 貯蔵環 境条件により, Table 1 に示す 6 つの試験区を用意し た. 1 袋 20 本を 1 試験区の供試本数とした. Table 1 の 気温は, 熱電対による袋内の実測值である. 恒温チャ ンバ内気温の設定值は, 袋内気温が $2.3 \pm 0.2^{\circ} \mathrm{C}$ の区 (暗黒) では $2.5^{\circ} \mathrm{C}, 6.8 \pm 0.2$ (暗黒) および $8.0 \pm 0.2^{\circ} \mathrm{C}$

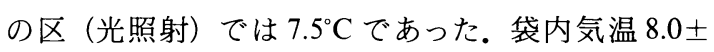
$0.2^{\circ} \mathrm{C}$ と $6.8 \pm 0.2^{\circ} \mathrm{C}$ との差 $1.2^{\circ} \mathrm{C}$ は, 袋外炽の弱光照 射による袋内気温の上昇分である。

光源には, 赤色発光ダイオード (SLZ-181B-20, (株) 三洋電機製; 以後, 赤色 LED) をユニバーサル基板に 設置密度 4 個 $/ \mathrm{cm}^{2}$ で設置したもの (以後, 赤色 LED アレイ）を用いた。袋上面における照射光の光合成有 効光量子束密度 (以下, PPFD) は, $1 \mu \mathrm{mol} \mathrm{m}^{-2} \mathrm{~s}^{-1}$ と した. $1 \mu \mathrm{mol} \mathrm{m}^{-2} \mathrm{~s}^{-1}$ のPPFD の設定は次の手順で 行った.まず,PPFD 0 から $6 \mu \mathrm{mol} \mathrm{m}^{-2} \mathrm{~s}^{-1}$ に対応する 照度計( $\mathrm{T}-1 \mathrm{M}$ ，ミノルタ(株)製)の読み取り值から, 赤 色 LED についての PPFD と照度間の一次関係式を求 めた。次に, 袋上面の照度を, $1 \mu \mathrm{mol} \mathrm{m}^{-2} \mathrm{~s}^{-1}$ の PPFD に相当する值 $(10 \mathrm{~lx})$ になるように, 同じ照度計を用い て設定した。PPFDの測定にはPPFD計（LI-190SA，

Table 1 Storage conditions for each treatment and its code name.

\begin{tabular}{cccc}
\hline $\begin{array}{c}\text { Treatment } \\
\text { code }\end{array}$ & $\begin{array}{c}\text { Temperature } \\
{\left[{ }^{\circ} \mathrm{C}\right]}\end{array}$ & $\begin{array}{c}\text { Low light } \\
\text { irradiation using } \\
\text { red LEDs }\end{array}$ & $\begin{array}{c}\text { Nutrient }^{\mathrm{Y}} \text { gel } \\
\text { application }^{-}\end{array}$ \\
\hline LDA & $2.3 \pm 0.2$ & no & yes \\
LDN & $2.3 \pm 0.2$ & no & no \\
MDA & $6.8 \pm 0.2$ & no & yes \\
MDN & $6.8 \pm 0.2$ & no & no \\
HRA & $8.0 \pm 0.2$ & yes & yes \\
HRN & $8.0 \pm 0.2$ & yes & no \\
\hline
\end{tabular}

$z$ Temperature in the transparent plastic bags used.

${ }^{Y}$ Hyponex $^{\circledR}(\mathrm{N}: 5, \mathrm{P}: 10, \mathrm{~K}: 5) 1000$ times-diluted solution gelled with $20 \mathrm{~g} \mathrm{~L}^{-1}$ agar.

$136(52)$
LI-COR 製) に電圧変換器（2290S, LI-COR 製）を接 続したものを用い, またその出力電圧の測定にはマル チメータ(TR6846，（株)アドバンテスト製）を用いた。

養液ゲルには，園芸植物用複合肥料（商品名：ハイ ポネックス (N:5, P: 10, K:5), 村上物産(株)製) の 1000 倍希釈液 $1 \mathrm{~L}$ を $20 \mathrm{~g}$ の粉末寒天でゲル化したも のを用いた、チャービルが収穫されたときの茎の切り 口側を養液ゲルに約 $1 \mathrm{~cm}$ 挿し込むことで, 貯蔵中に チャービルが養液ゲルから水および養分を吸収できる ようにした。

測定項目は, 葉色, 生体重, および乾物重とした。 葉色は, 0 日目 (貯蔵開始日) から 2 日おきに各試験区 ごとに同一個体 1 本のチャービルについて色彩色差計 (CR-200b，ミノルタ(株)製)を用いて測定した. 表色 系には $L^{*} a^{*} b^{*}$ 表色系を用いた。生体重および乾物量 は 0 日目拉よび 21 日目（貯蔵終了日）に測定した。 0 日目の乾物重は, 貯蔵に用いたチャービルと同時に収 穫されたもの 40 本の平均乾物重と等しいと仮定した.

\section{結果および考察}

貯蔵中のチャービルの $L^{*}$ (明度), $a^{*}$ (色度 : 緑赤), $b^{*}$ (色度：青-黄）および $\Delta E^{*} a b$ (色差) の経日 変化を Fig. 1 に示す. $L^{*}$ の值の増加は明度の増加を, $a^{*}$ の值の増加は $a^{*}$ の值が負の範囲であれば緑色の減 少を, $b^{*}$ の值の増加は $b^{*}$ の值が正の範囲であれば黄 色の増加を, $\Delta E^{*} a b$ の值は 0 日目（貯蔵開始日）との 色差をそれぞれ示している。

赤色 LED 弱光照射を行い養液ゲルを利用した HRA 区は，暗黒下で養液ゲルを利用したMDA 区と 比較して袋内気温が $1.2^{\circ} \mathrm{C}$ 高いにもかかわらず, HRA 区の $L^{*}, a^{*}, b^{*}$ および $\Delta E^{*} a b$ の值は, MDA 区のそれ らとほほ同様に推移した。このことは, 水および養分 の供給源がある条件下で赤色 LED による弱光照射を 行えば，暗黒下におけるよりも高い気温で，暗黒下と 同程度の期間の貯蔵が可能であることを示している. 同様な結果は, 白色蛍光灯を光源として行われた Heins et al. (1994) の花卉セル成型苗の貯蔵試験にお いても得られている。 また, HRA 区より $5.7^{\circ} \mathrm{C}$ 低い LDA 区と比較すると, HRA 区の $L^{*}, a^{*}, b^{*}$ おび $\Delta E^{*} a b$ の值は, LDA 区のそれらと 15 日目まではほと んど等しかったことから, 葉色の保持に関しては, 2 週 間程度の期間であれば, 赤色 LED 弱光照射は, $5.7^{\circ} \mathrm{C}$ も低い気温と同様の効果を有するといえる.

緑色青果物の貯蔵における赤色光照射の有効性に関

生物環境調節 (Environ. Control in Biol.) 

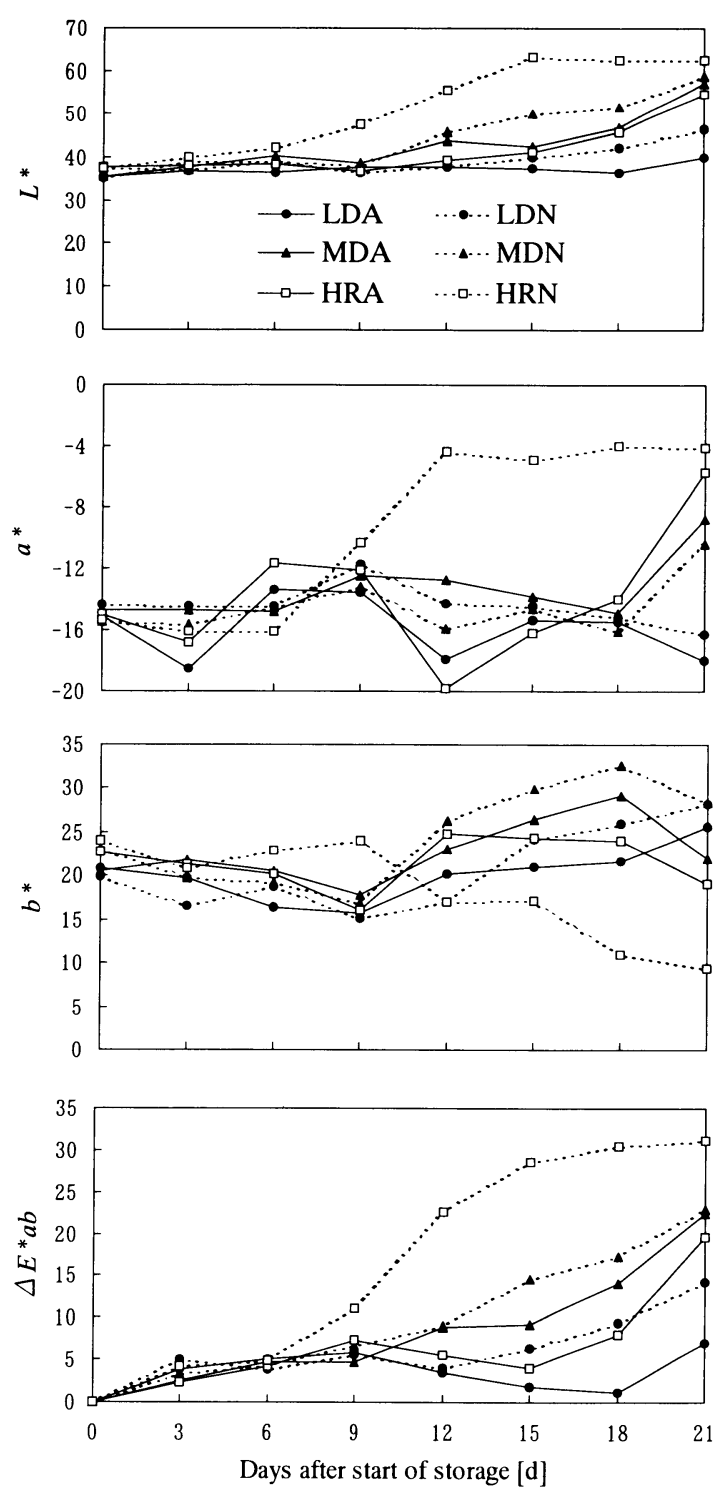

Fig. 1 Time course of chromaticity $\left(L^{*}:\right.$ metric lightness; $a^{*}$ : green-red chromaticity; $b^{*}$ : blueyellow chromaticity; $\Delta E^{*} a b$ : color difference) values of postharvest chervil during storage in each treatment.

See Table 1 for the treatment codes.

しては, 収穫後のコマツナの内容成分保持に対して, 放射照度 (単位： $\mathrm{W} \mathrm{m}^{-2}$ ) が等しい場合は波長 $660 \mathrm{~nm}$ 付近の光（赤色光）が最も有効であることを示した Hosoda et al. (1985)の報告がある.この報告は, Inada （1976）が成育中の 30 種余りの緑色植物の光合成のス ペクトル依存性について示した結果, すなわち, 単位
放射照度当たりの光合成速度のピークは, およそ波長 630 から $690 \mathrm{~nm}$ の間にあるとした結果とも一致して いる.また,ブロッコリ組織培養苗 (Kubota and Kozai, 1994）やナスセル成型苗（Kozai et al., 1996）の低温 貯蔵における弱光照射の主な効果は, 呼吸速度と等し い速度で, 弱光照射により植物体に光合成を行わせ, 乾物重を維持することにあると説明されている.これ らの報告は, 貯蔵期間中の弱光照射用光源としては, 単位放射照度当たりの光合成速度が最も大となる 660 $\mathrm{nm}$ 付近の光を照射する赤色 LED が好適であること を支持するものと考える.なお, LED が低温貯蔵にお ける弱光照射用光源として好適であることはFujiwara et al. (1996) が指摘している.

$L^{*}, a^{*}$ および $\Delta E^{*} a b$ の值は, 養液ゲルを利用しな

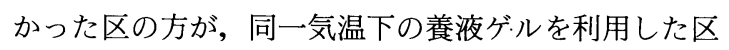
よりも高く推移する，すなわち明度 (白っぽさ) 増加, 緑色減少, および葉色変化が大となる傾向であった。 特に, 赤色 LED 弱光照射を行い養液ゲルを利用しな

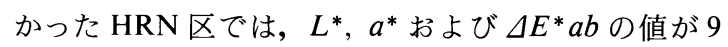
日目以降，他の試験区より顕著に大であった。また， HRN 区ではそれらの值が 9 日目以降, HRA 区より高 く推移したことから, 養液ゲルを利用することで葉色 変化を抑制できることが明らかとなった．HRN 区で は養液ゲルを利用しなかったため, 弱光照射により促 進された蒸散に見合う量の水や光合成に必要な無機成 分が供給されず, 結果的に, 品質の低下が加速された ものと推察できる.

上記の結果は,多くの緑色青果物や挿し穂のように, 水や養分の供給源がない条件下にある植物体に対して 弱光照射を行うと，その品質低下を加速する場合のあ ること,およびそのような場合にはここで用いた養液 ゲルのような水や養分を供給するためのもの, あるい は供給するための処置が必要となることを示してい る. 花卉セル成型苗 (Heins et al., 1994), ブロッコリ 組織培養苗 (Kubota and Kozai, 1994), ナスセル成型 苗(Kozai et al., 1996), カイワレダイコン(Kobayashi et al., 1996) などの低温貯蔵に対して弱光照射の効果 が認められているのは, それらの植物体が水と養分, あるいは水のみを吸収できる条件下にあったためで あったと理解できる.

なお，種々の緑色植物の低温貯蔵期間延長のために 利用する養液ゲルなどに好適な無機成分組成は, 成育 抑制が貯蔵の第一目的であることから考えて，一般の 水耕栽培養液のそれとは異なるはず（Fujiwara et al., 
1996）である．また，取り扱い容易な方式が考案され れば，水や養分の供給は，液体として行う方が有効な 場合もあると考える。

$L^{*}, a^{*}, b^{*}$ および $\Delta E^{*} a b$ の経日変化を総合的にみ て, 0 日目からの変化が最も小さかったのは, 袋内気温 $2.3^{\circ} \mathrm{C}$, 暗黒, 養液ゲル利用の LDA 区であり, 他方最 も大きかったのはHRN 区であった。 また, 21 日目(貯 蔵終了日）において, 最も高い外観品質を保持してい たのは LDA 区であり, 逆に外観品質が最も低かった のはHRN 区であった。供試したチャービルについて は, 外観品質の高さは, $\Delta E^{*} a b$ の值の小ささで評価す るのが最も適当であると思われた。

21 日目の生体重および乾物重を Fig. 2 に示す. 貯蔵 前と比較して危険率 $5 \%$ レベルで有意差が認められた のは,それぞれ生体重においてはHRN 区, 乾物重にお いてはHRA 区のみであった.HRN 区で生体重が有意 に隇少したのに対して，HRA 区ではそうでなかった
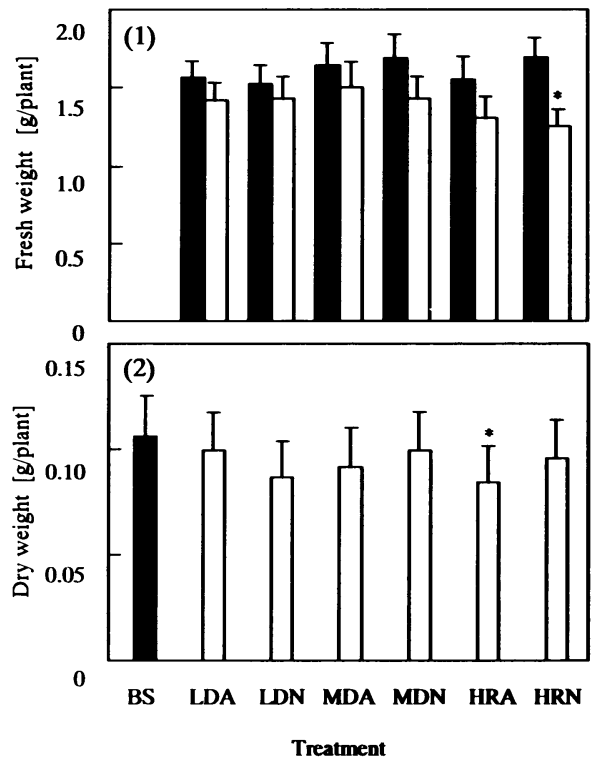

Fig. 2 Fresh (1) and dry (2) weights of postharvest chervil before (black) and 21 days after storage (white) in each treatment.

Vertical bars represent standard errors of the mean $(n=20)$, and asterisks $\left({ }^{*}\right)$ indicate treatments of which mean was significantly different at the $5 \%$ level by $t$-test from the mean before storage. Dry weight before storage (BS) is the mean weight for all treatments, which is obtained by drying all the chervil after fresh weight measurement for each treatment. See Table 1 for the treatment codes.
ことから, 弱光照射を行う場合には, 養液ゲル利用が チャービルの生体重維持に有効であったことがわか る. 他方, HRA 区の乾物重が有意に減少したことか ら, $8^{\circ} \mathrm{C}$ におけるチャービルの貯蔵に対しては, PPFD $1 \mu \mathrm{mol} \mathrm{m}{ }^{-2} \mathrm{~s}^{-1}$ は低かったものと推定できる. Kozai et al. (1996) は, 気温 $9^{\circ} \mathrm{C} て ゙$ 貯蔵したナスセル成型苗の 乾物重が, 暗黒下では貯蔵前よりも低下し, PPFD 5 $\mu \mathrm{mol} \mathrm{m}^{-2} \mathrm{~s}^{-1}$ 下では増減なく, それ以上の PPFD 下で は増加することを示している。

現在著者らは, 温度, PPFD, および養液ゲル利用の 有無の 3 因子の影響を統計分析可能な貯蔵試験, なら びにCA (Controlled Atmosphere) を弱光照射と組み 合わせた貯蔵（弱光照射 CA 貯蔵）の試験を進めてい る.

供試植物のチャービルをご提供下さったセコムハイ プラント(株)ならびに同社奥田真弘氏に深甚の謝意を 表する．低輝度赤色 LED および養液ゲルを利用する 着想は, 千葉大学園芸学部教授古在豊樹博士との議論 から得られたものである. 記して謝意を表す。なお, 本研究は, 平成 8 年度文部省科学研究費 (課題番号: 08760241）の補助を受けて行った。

\section{文献}

Cantwell, M., Reid, M. 1990. Postharvest handling systems : Fresh herbs. In "Postharvest Technology of Horticultural Crops" (ed. by Kader, A. A.), Ed. 2, University of California, California, p 211-213.

Fujiwara, K., Kubota, C., Kozai, T. 1996. Low light irradiation for low temperature storage of plug seedlings. (Japanese text) Agricul. Horticul. 71 : 699-704.

Heins, R., Lange, N., Wallace, T. F., Jr., Carlson, W. 1994. Plug Storage, Greenhouse Grower, Ohio, pp 19.

Hosoda, H., Kurogi, M., Matsuoka, T. 1985. Effect of light quality on changes in nutrients content of detached Komatsuna leaves. (Japanese text) Abst. autumn meeting of Jap. Soc. Hort. Sci., p 492-493.

Inada, K. 1976. Action spectra for photosynthesis in higher plants. Plant Cell Physiol. 17 : 355-365.

Kubota, C., Kozai, T. 1994. Low-temperature storage for quality preservation and growth suppression of broccoli plantlets cultured in vitro. HortScience 29 : 1191-1194.

Kobayashi, R., Takagaki, M., Kubota, C., Kozai, T. 1996. Effect of dim light during low temperature storage on the postharvest quality of radish sprouts. (Japanese text with English abstract and captions) Envion. Control in Biol. 34 : 153-155.

Kozai, T., Kubota, C., Sakami, K., Fujiwara, K., Kitaya, Y. 1996. Growth suppression and quality preservation of eggplant plug seedlings by low temperature storage under dim light. (Japanese text with English abstract and captions) Environ. Control in Biol. 34 : 135-139. 